\title{
МОЛОЧНА ПРОДУКТИВНІСТЬ ТА ВІДТВОРЮВАЛЬНА ЗДАТНІСТЬ КОРІВ ЗАЛЕЖНО ВІД ГЕНЕТИЧНИХ ТА ПАРАТИПОВИХ ЧИННИКІВ
}

\author{
Шпетний Микола Борисович \\ кандидат сільськогосподарських наук, доцент \\ Сумський національний аграрний університет \\ ORCID: 0000-0003-4757-5875/ W-3978-2018 \\ E-mail: nshpetny@gmail.com
}

Заболотна Віра Костянтинівна студентка біолого-технологічного факультету Сумський національний аграрний університет ORCID: 0000-0001-5020-5109 E-mail: verazabolotnaya1410@gmail.com

Гришин Сергій Юрійович студент біолого-технологічного факультету Сумський національний аграрний університет ORCID: 0000-0002-8303-0293 E-mail: gryshynf1@gmail.com

Проведено дослідження з вивчення ознак молочної продуктивності та відтворювальної здатності тварин голштинської та української чорно-рябої молочної порід в умовах промислового підприємства «Глобинський м'ясомолочний комплекс» Полтавської області. Встановлено міжпородну мінливість за величиною надою згідно якої лідирують корови голштинської породи з надоєм 7334 ке за даними першої лактації з перевищенням ровесниць української чорно-рябої на 609 кг ( $P<0,001)$. За даними другої, третьої та кращої лактацій перевага за надоєм склала відповідно 1542 i 2531, 1678 і 2581 та 2179 і 3237 ке за високої та достовірної різниці в усіх порівняннях. Порівняльний аналіз показників відтворювальної здатності корів засвідчив, що голштини виявились більш скороспілими, оскільки вперше осіменились у віці 461,6 дня, що на 42,4 дня раніше ніж ровесниці української чорно-рябої молочної породи. Тривалість сервіс-періоду корів голштинської породи становила 109 днів, що менше ніж у ровесниць української чорно-рябої молочної породи, різниия у 14 днів виявилася високодостовірною ( $P<0,001)$. Різниця за живою масою ремонтних телиць голштинської породи у 19 кг в порівнянні з ровеснииями української чорно-рябої достовірна на рівні останнього порогу $(P<0,001)$, так само як $i$ жива маса при першому отеленні на 35 ка. Встановлено достовірний вплив віку першого плідного осіменіння телиць та отелення на показники молочної продуктивності. Вищі показники за надоєм першої лактації та довічним надоєм у корів української чорно-рябої молочної породи виявились при їх запліднені у 16-17 місяців і розтеленні у 25-26 місяців з надоєм за першу лактацію та за життя відповідно 6952 та 37674 кг, а у корів голштинської породи ці показники відповідно становили 7412 та 44274 ке. Виявлена достовірна мінливість показників відтворювальної здатності дочірнього потомства бугаїв-плідників оцінених ліній у межах піддослідних порід. Встановлені коефіцієнти кореляції між віком при першому отеленні та надоєм, які становили від низьких (r=0,087) до помірних $(r=0,214)$ і залежали від лактації. Найвища кореляція, отримана у віці кращої лактації (r=0,274) свідчить, що добір за віком при першому отеленні може бути певною мірою ефрективним. За вмістом жиру в молоці від'ємні кореляції $(r=-0,032 \ldots-0,085)$ вказують на відсутність ефективної селекції за цією ознакою. Тоді як добір за виходом молочного жиру буде також ефективним (r=0,095-0,303), особливо за кращу лактацію. Про ефеективність селекиії за добором корів з урахуванням віку при першому отеленні свідчать показники сили впливу за усіма ознаками молочної продуктивності, які найвищі за величиною надою, особливо за кращу лактацію (31,4\%), та загальним виходом молочного жиру (28,5\%).

Ключові слова: голштинська, українська чорно-ряба молочна, надій, жир, білок, відтворні якості, кореляція, сила впливу.

DOI: https://doi.org/10.32845/bsnau.Ivst.2021.4.6

Селекція спеціалізованих молочних порід ірунтується найперше на доборі тварин за ознаками молочної продуктивності, що є відповідно закономірним заходом. Інші ознаки або знаходяться у співвідносній мінливості, або обов'язково присутні задля отримання молочної продукції з найменшими затратами упродовж якомога довшого терміну продуктивного використання, які забезпечують міцне здоров'я тварин, добру відтворювальну здатність та високу адаптацію до несприятливих умов паратипових чинників. Вплив на ознаки молочної продуктивності чинять спадкові фактори - порода [16, 21, 23, 26], належність до генеалогіч- ного формування $[3,5,11,21,27,28]$, частка спадковості поліпшуючої породи $[22,28,29]$ та паратипові - жива маса у різні вікові періоди, сезон та вік народження, першого плідного осіменіння та першого отелення [12, 21].

Дослідження [4] доводять, що більш високою молочною продуктивністю характеризуються корови голштинської породи, які отелилися у віці 25-26 місяців. Інші автори [1] повідомляють, що найбільшим продуктивним довголіттям відрізнялися чорно-рябі корови з віком першого отелення до 30 місяців. Це дає можливість отримувати від них за 5,59 ... 6,51 лактацій 24658 ... 41714 кг молока і 127,7 ... 130,6 кг 
молочного жиру. Кращі показники (6,51 лактацій) відзначені у корів, які отелилися перший раз до 27-міс. віку. При підвищенні живої маси телиць (до оптимальної) на кожні 10 кг удій зростає на 127,3 кг у білоруської чорно рябої породи і на 161,8 кг у голштинської породи [12]. Корови-первістки, які, бувши телицями, були запліднені у віці 13-14 місяців (контрольна група) за надоєм переважали тварин, які запліднилися у пізніші терміни (дослідна група) на 398,9 кг у першу лактацію та на 463,6 кг - у другу [13]. Повідомляється [21], що за наявного впливу породи та лінії на величину надою 3 різницею між голштинською та українською чорно-рябою молочною у межах 601,2-1431,2 кг на користь голштинської, сила впливу фактору породи становила відповідно лише 5,88 та 2,96\%. За дослідженнями відтворних якостей ліній чорно-рябих корів встановлено їхній вплив на тривалість сервіс та міжотельного періодів [7].

Враховуючи багатогранність факторів впливу на показники молочної продуктивності та відтворювальної здатності метою досліджень стало вивчення особливостей цих показників у корів оцінюваних молочних порід у порівняльному аналізі та впливу генетичних та паратипових чинників на мінливість показників відтворювальної здатності корів.

Матеріали та методи досліджень. Базою для проведення експериментальних досліджень стало підприємство з розведення молочної худоби різних порід ТОВ "НВП "Гло- бинський м'ясомолочний комплекс".

Досліджувалися тварини трьох порід із яких основними були тварини, які представлені найбільшою кількістю у господарстві - української чорно-рябої молочної (УЧРМ) 3 високою часткою спадковості у їхньому генотипі голштинської породи (ГП). У стаді присутнє також незначне поголів'я української червоно-рябої молочної породи (УЧеРМ). Крім того у цьому господарстві розводиться голштинська порода чорно-рябої масті завезена із Канади у 2014 році. Для досліджень з визначення показників господарськи корисних ознак використана інформація з бази даних автоматизованої системи ведення селекційно-племінного обліку СУМС "Інтесел Орсек". Біометричне опрацювання експериментальних даних - статистичний, кореляційний та дисперсійний аналізи проводили за формулами, наведеними Е.К. Меркурьевой [17] на ПК з використанням власного програмного забезпечення. Результати вважали статистично достовірними, якщо $\mathrm{P}<0,05\left(^{*}\right), \mathrm{P}<0,01\left(^{* *}\right), \mathrm{P}<0,001\left(^{* * *}\right)$.

Результати досліджень. Порівняльний аналіз ознак, які характеризують молочну продуктивність корів різних порід - величина надою, масова частка жиру та білка корів, які лактують в однакових умовах годівлі та утримання, засвідчив істотну міжпородну мінливість оцінюваних ознак, табл. 1.

Таблиця 1

Молочна продуктивність корів різного походження у динаміці лактацій, (x \pm S.E.)

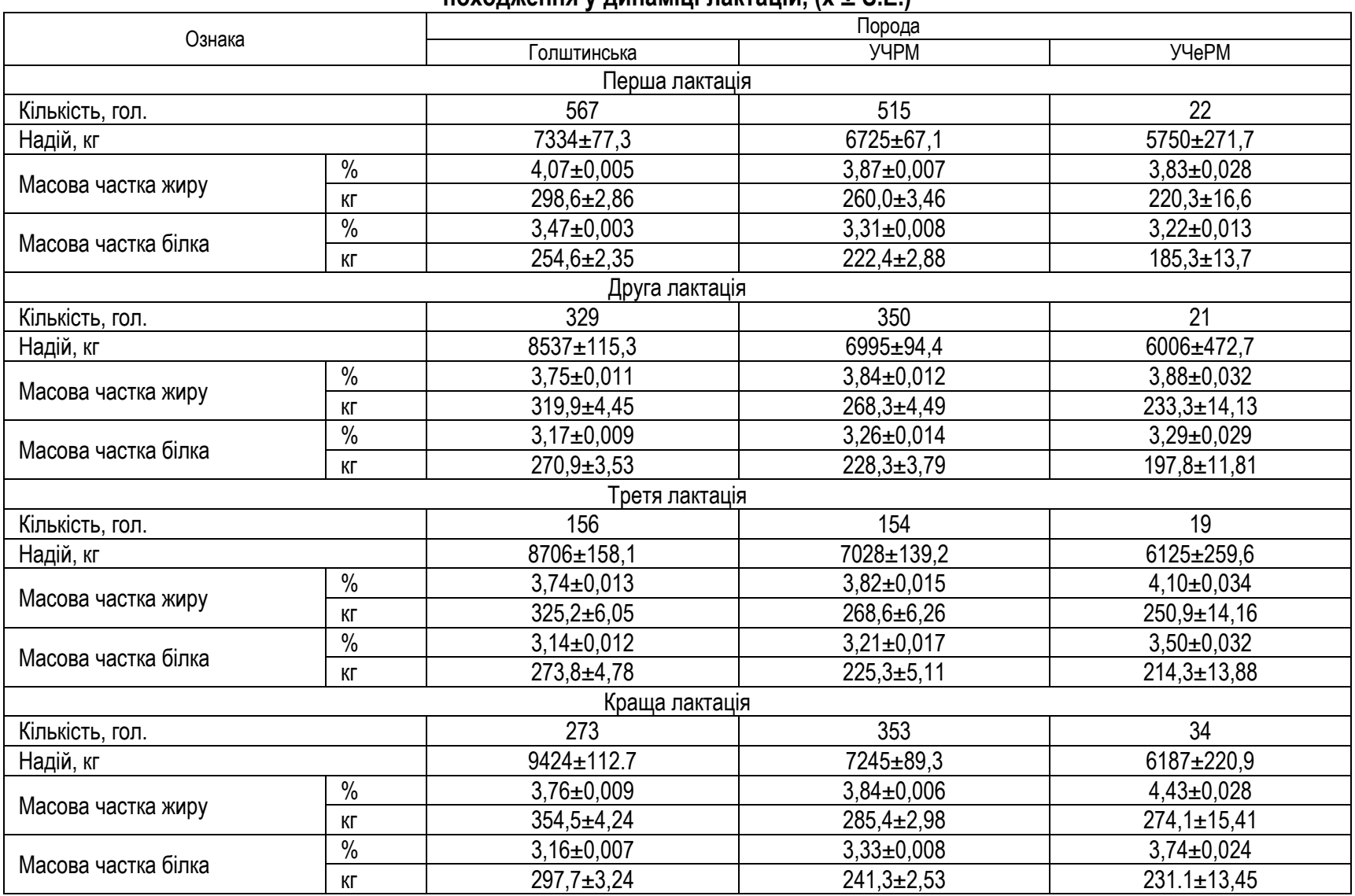

За величиною надою за даними першої лактації лідирують корови голштинської породи 3 надоєм 7334 кг 3 високодостовірним перевищенням ровесниць української чорно-рябої на 609 кг (Р<0,001) та червоно-рябої - на 1584 кг $(P<0,001)$. За даними другої, третьої та кращої лактацій перевага за надоєм склала відповідно 1542 і 2531, 1678 і 2581 та 2179 і 3237 кг за високодостовірної різниці в усіх порівняннях $(\mathrm{P}<0,001)$. 
За оцінкою якісних показників молока також спостерігалася міжпородна мінливість як за масовою часткою жиру, так і білка. Так, корови первістки голштинської породи, не дивлячись на існування існуючого генетичного антагонізму, тобто від'ємної кореляції між величиною надою та жирністю молока, виявились кращими і за показниками жирномолочності та білковомолочності. За масовою часткою жиру вони перевершували корів-первісток українських чорно-рябої та червоно-рябої молочних відповідно на 0,20 та 0,24\%, а за масовою часткою булка - на 0,16 та 0,25\% (P<0,001).

Разом з тим, зростання надою у корів голштинської породи за наступними лактаціями підтвердило негативну співвідносну залежність між кількістю та якістю молока, тобто вміст жиру і білка з кожним збільшенням надою за старші лактації дещо знижувався.

За даними другої лактації голштинські корови поступалися українським чорно-рябим та червоно-рябим за вмістом жиру відповідно на 0,09 та 0,13\% з високодостовірною різницею при $\mathrm{P}<0,001$.

Аналогічно корови голштинської породи за показниками у віці другої лактації поступалися і за вмістом білка, відповідно з високодостовірною різницею - на 0,09 та 0,71\% $(P<0,001)$.

За даними повновікової третьої лактації найвищою жирномолочністю та білковомолочністю помітно відрізнялися корови української червоно-рябої молочної породи, які перевершували за цими ознаками корів голштинської відповідно на 0,36\%, а української чорно-рябої - на 0,36 та 0,29\% $(P<0,001)$.

За показниками кращої лактації перевага корів української червоно-рябої молочної породи за вмістом жиру та білка склала відповідно у порівнянні з голштинами 0,67 та 0,59, а української чорно-рябої - на 0,59 та 0,41\% ( $\mathrm{P}<0,001)$.

Практикою зоотехнії доведено, що відтворна здатність молочних корів - це важлива складова при комплексній оцінці молочної худоби. Оскільки регулярні, щорічні отелення, на переконання автора [14], забезпечують потужний фізіологічний стимул наступним лактаціям, а одержаний приплід дозволяє вести розширене відтворення молочного стада, підвищити економічну ефективність виробництва продукції молока та реалізації племінного молодняку. Враховуючи вище наведене, можна стверджувати, що плодючість корів, поряд з їх молочністю, є провідною ознакою се- лекції.

Економічна ефективність ведення галузі молочного скотарства істотним чином залежить від низки показників відтворювальної здатності корів, які впливають на інтенсивність ремонту стада, тривалості сервіс- та міжотельного періоду, кількість витрачених спермодоз на одне плодотворне осіменіння, вік та живу масу телиць при першому осіменінні та отеленні первісток, реалізацію генетичного потенціалу продуктивності тощо.

Цими ж авторами [14] повідомляється, що голштинська худоба характеризується задовільними показниками відтворної здатності, які зумовлені фрізіологічними особливостями високопродуктивних тварин. Вважається, що із збільшенням рівня продуктивності вище за 7000 кг молока спостерігається і збільшення міжотельного періоду. Слід відмітити, що голштинські тварини вимогливі до якості годівлі та умов утримання і свої найкращі властивості можуть проявити тільки за оптимальних умов. 3 огляду на природний антагонізм ознак величини надою та відтворної здатності і резистентності, корови голштинської породи відзначаються переважно надміру тривалим періодом між отеленнями, за даними досліджень (441-487 днів) та відповідним сервісперіодом - 150-205 днів [14]. Про подовжені сервіс- та міжотельний періоди голштинської худоби в Україні повідомляють й інші автори [28], згідно яких їхня тривалість становила відповідно 142 та 421 день.

За дослідженнями [20], проведеними в умовах молочного комплексу ПрАТ "Агро-Союз" на тваринах голштинської породи, яких утримували у легких корівниках з боксами для відпочинку та кормовим столом для споживання загальних змішаних раціонів, також встановлені досить високі показники тривалості сервіс-періоду (377,7-419,0 днів) та міжотельного періоду (662,7-704,0 дні). Ці автори вважають, що порівняно невисока відтворна здатність і короткий період господарського використання $€$ основними недоліками голштинської породи.

Наші дослідження спростовують вище наведені показники, оскільки за створення відповідних умов голштинські корови в умовах підконтрольного господарства відрізняються достатньо високими показниками відтворної здатності, які $€$ навіть кращими за аналогічні у корів української чорнорябої молочної, табл. 2.

Характеристика порід стада за відтворювальними якостями, X \pm S.E.

\begin{tabular}{|l|c|c|}
\hline \multicolumn{1}{|c|}{ Показники } & \multicolumn{2}{|c|}{ Порода } \\
\cline { 2 - 3 } & $\begin{array}{c}\text { українська чорно-ряба молочна } \\
(\mathrm{n}=796)\end{array}$ & $\begin{array}{c}\text { голштинська } \\
\text { ( } \mathrm{n}=1435)\end{array}$ \\
\hline Вік першого осіменіння, днів & $504 \pm 4,2$ & $461,6 \pm 4,0$ \\
\hline Вік першого отелення, днів & $788 \pm 8,4$ & $748 \pm 0,06$ \\
\hline Тривалість сервіс-періоду, днів & $123 \pm 2,2$ & $109 \pm 1,4$ \\
\hline Тривалість тільності, днів & $278,3 \pm 3,3$ & $276,4 \pm 3,4$ \\
\hline Тривалість першої лактації, днів & $401 \pm 5,1$ & $385 \pm 4,5$ \\
\hline Кількість осіменінь на одну телицю, шт. & $1,7 \pm 0,07$ & $1,4 \pm 0,05$ \\
\hline Кількість осіменінь на одну корову післяпершого отелення, шт. & $2,4 \pm 0,14$ & $2,1 \pm 0,12$ \\
\hline Жива маса ремонтних телиць при 1-му осіменінні, кг & $368 \pm 2,8$ & $387 \pm 2,6$ \\
\hline Жива маса корів при 1-му отеленні, кг & $539 \pm 3,1$ & $574 \pm 4,3$ \\
\hline
\end{tabular}

Порівняльний аналіз показників відтворювальної здатності тварин голштинської та української чорно-рябої молочної порід в аналогічних умовах одного підприємства засвідчив, що голштини виявились більш скороспілими, оскільки вперше осіменились у віці 461,6 дня, що на 42,4 дня раніше ніж ровесниці української чорно-рябої молочної породи, різниця висока та достовірна ( $\mathrm{P}<0,001 ; \mathrm{td}=7,31)$. Відповідно й отелення нетелів голштинської породи сталося 
достовірно раніше на 40 днів порівняно з ровесницями УЧРМ породи.

Наразі вважається, що оптимальна тривалість міжотельного циклу корови - 365 днів (12 місяців), для високопродуктивної - 375 днів (12,5 місяців). Тобто, міжотельний цикл $=80$ днів сервіс-період + 285 днів тільність $=365$ днів; або: 90 днів сервіс-період + 285 днів тільність $=375$ днів.

Численними дослідниками [6, 10, 25] доведено, що молочна продуктивність корів залежить від тривалості сервіс-періоду. Фізіологічно обґрунтовано, що чим раніше після отелення покрита корова, тим швидше настає гальмівний вплив тільності на секрецію молока і лактація буде коротшою. При подовженні сервіс-періоду створюються більш сприятливі умови для рівномірного перебігу лактації та прояву високої продуктивності. Однак таке подовження відсуває наступне отелення, а іноді від пропуску декількох тічок корова залишається яловою. За період господарського використання від таких корів отримують менше телят і молока.

Оптимальний термін післяпологового осіменіння корів повинен бути обраний залежно від породності, продуктивності, віку тварин, вгодованості та інших факторів. Але у всіх випадках необхідно прагнути до того, щоб від кожної корови отримати одне теля на рік. Для цього її потрібно парувати через 50-60 днів після отелення (але не пізніше 80 днів). Високопродуктивних, молодих і недостатньо вгодованих корів потрібно парувати під час другої, а іноді і третьої охоти, але в межах невеликих відхилень від зазначених термінів. Висока ефективність використання корів може бути досягнута при міжотельних періодах близько 12 місяців, 3 них 10 місяців має припадати на лактацію і 2 на сухостійний період [19].

За результатами наших експериментів тривалість сервіс-періоду корів голштинської породи була порівняно 3 літературними даними не настільки значною - 109 днів, що навіть менше ніж у ровесниць української чорно-рябої молочної породи, різниця у 14 днів виявилася високодостовірною при $P<0,001$. Оскільки сервіс-період визначає тривалість міжотельного періоду, то від також був на користь голштинських корів з перевагою українських чорно-рябих на 16 днів $(P<0,001)$. Кількість осіменінь на одну телицю та корову після першого отелення виявився на користь тварин голштинської породи, що є добрим економічним показником, оскільки спермопродукція з часом дорожчає.

Жива маса ремонтних телиць визначає час першого осіменіння і $€$ запорукою подальшого розвитку тварини і відповідної реалізації молочної продуктивності у дорослому стані, що підтверджується результатами досліджень [9].

За результатами наших досліджень різниця за живою масою ремонтних телиць голштинської породи у 19 кг в порівнянні з ровесницями української чорно-рябої молочної достовірна на рівні останнього порогу ( $\mathrm{P}<0,001)$, так само як і жива маса при першому отеленні на 35 кг $(\mathrm{P}<0,001)$.

Найважливішим і разом з тим найскладнішим проблемним питанням у галузі молочного скотарства, особливо в умовах його технологічної інтенсифікації, $є$ забезпечення високого рівня молочної продуктивності корів з одночасним довготривалим господарським та продуктивним використанням, наголошується авторами досліджень [15]. Продуктивне довголіття корів $є$ досить складною інтегральною ознакою, яка детермінується як генетичними, так і паратиповими чинниками. Складність селекції за ознакою довголіття полягає у тому, що фактична оцінка за показниками цих ознак є можливою лише після вибуття корів зі стада, а, отже, вибуття із селекційного процесу як такого [15].

Тому важливим чинником $€$ пошук непрямих предикторів задля їхнього використання на ранніх етапах селекційної роботи з молочною худобою. До них можна віднести і вік телиць при першому плідному осіменінні.

3 цього приводу повідомляється [8], що корови чорно-рябої породи, які отелилися у більш ранньому віці, за перші лактації мають нижчі надої, порівняно з тваринами старшого віку, але в подальшому ця різниця скорочувалася і за довічним надоєм вони переважали корів, які отелилися у старшому віці. Автор вважає, що оптимальним віком першого отелення $€ 28$ місяців, але при цьому потрібно враховувати не лише породні особливості тварин, їх індивідуальний розвиток, але й господарські умови. За даними іншого дослідника [2], корови української чорно-рябої молочної породи, які отелилися раніше 26-місячного віку, характеризувалися найвищими довічними надоями, найбільшою тривалістю господарського використання та коефіцієнтом господарського використання. Однак, надої за першу лактацію у цих тварин були найменшими. Коефіцієнти кореляції між віком першого отелення і показниками тривалості господарського використання, тривалості життя, тривалості лактування та довічного надою у більшості випадків були від'ємними. Оптимальним віком першого отелення корів сумського внутрішньопородного типу української чорно-рябої молочної породи наступний автор [18] вважає 27-29 місяців. Наступними дослідженнями [24] встановлено, що для подовження тривалості продуктивного використання корів голштинської, української чорно-рябої та червоно-рябої молочних порід їх перше отелення потрібно планувати у віці 27,1-29,0 місяців, а для підвищення довічної продуктивності - 25,1-27,0 місяців.

На переконання автора [30] генетичні кореляції між надоєм за 305 днів лактації та віком першого отелення у великої рогатої худоби Бразілії, які виявилися від'ємними (0,49), показують сприятливу асоціацію. Наступні автори [31] при дослідженні корів Чехії констатували, що підвищені надої молока знижують характерні ознаки відтворення за рахунок подовження днів сервіс-періоду та інтервалу між отеленнями. Розрахункова кореляція між надоями та сервісперіодом була наступною: $r=0,38$ для надоїв, $r=0,32$ для виходу жиру і r=0,25 для виходу білка.

Як впливає вік телиць за першого осіменіння на продуктивне довголіття корів української чорно-рябої молочної породи можна спостерігати за показниками табл. 3.

Про достовірний вплив віку ремонтних телиць на показники довголіття свідчать отримані результати наших досліджень, згідно яких вищі показники за надоєм першої лактації та довічним надоєм виявилися у корів, які вперше були запліднені у віці 16-17 та 18-19 місяців. Проте перше місце за цими ознаками зайняли корови запліднені у 16-17 місяців і розтеленні у 25-26 місяців з надоєм за першу лактацію та за життя відповідно 6952 та 37674 кг.

Їхні перевага за довічним надоєм виявилась достовірною у порівнянні з тваринами, які вперше були запліднені у віці 14-15 місяців з різницею 8551 кг ( $\mathrm{P}<0,001)$, у 20-21 місяць - 6519 кг $(P<0,001)$ та 22 і старше - 9890 кг $(P<0,001)$. Корови цієї ж групи (вік осіменіння 16-17 міс.) довше лактували - на 09-1,2 лактації $(\mathrm{P}<0,01)$.

Вісник Сумського національного аграрного університету 
Таблиця 3

Вплив віку телиць за першого плідного осіменіння

на продуктивне довголіття корів української чорно-рябої молочної породи

\begin{tabular}{|c|c|c|c|c|c|c|}
\hline \multirow{3}{*}{ Голів } & \multirow{3}{*}{$\begin{array}{l}\text { Вік при першому } \\
\text { заплідненні, міс. }\end{array}$} & \multicolumn{2}{|c|}{ Жива маса, кг } & \multicolumn{2}{|c|}{ Надій, кг } & \multirow{2}{*}{$\begin{array}{c}\text { Кількість лактацій, } \\
\text { шт. }\end{array}$} \\
\hline & & перше запліднення & перше отелення & перша лактація & довічний & \\
\hline & & \multicolumn{5}{|c|}{$\mathrm{X} \pm$ S.E. / Cv, \% } \\
\hline \multirow{2}{*}{97} & \multirow{2}{*}{$14-15$} & $349 \pm 8,5$ & $495 \pm 9,4$ & $6351 \pm 341,6$ & $29123 \pm 852,5$ & $4,2 \pm 0,31$ \\
\hline & & 10,1 & 8,7 & 21,4 & 17,1 & 14,6 \\
\hline \multirow{2}{*}{124} & \multirow{2}{*}{$16-17$} & $362 \pm 7,9$ & $522 \pm 8,9$ & $6952 \pm 312,1$ & $37674 \pm 742,4$ & $5,3 \pm 0,27$ \\
\hline & & 8,6 & 9,5 & 21,7 & 12,8 & 13,2 \\
\hline \multirow{2}{*}{137} & \multirow{2}{*}{$18-19$} & $374 \pm 4,6$ & $533 \pm 8,2$ & $6521 \pm 311,5$ & $36439 \pm 689,5$ & $5,1 \pm 0,31$ \\
\hline & & 6,3 & 7,8 & 21,2 & 19,7 & 13,4 \\
\hline \multirow{2}{*}{55} & \multirow{2}{*}{$20-21$} & $383 \pm 5,7$ & $544 \pm 10,5$ & $6221 \pm 296,8$ & $31155 \pm 741,4$ & $4,4 \pm 0,28$ \\
\hline & & 10,4 & 9,9 & 27,6 & 14,5 & 15,7 \\
\hline \multirow{2}{*}{22} & \multirow{2}{*}{22 і старше } & $397 \pm 10,5$ & $558 \pm 9,9$ & $5877 \pm 263,4$ & $27784 \pm 811,5$ & $4,1 \pm 0,32$ \\
\hline & & 11,2 & 10,4 & 24,3 & 14,8 & 13,8 \\
\hline
\end{tabular}

Аналогічна ситуація спостерігалася і за дослідженнями впливу віку телиць за першого плідного осіменіння на продуктивне довголіття корів голштинської породи, табл. 4.

За даними цих досліджень найвища продуктивність за першу лактацію та за усе життя також була у корів, які вперше були запліднені у віці 16-17 місяців з надоями відповідно 7412 та 44274 кг. Їхня перевага за надоєм першої лактації склала від 647 кг (група осіменіння у віці 22 міс. і старше) до 197 кг (група осіменіння у віці 18-19 міс.) проте різни- ця в усіх порівняннях виявилася недостовірною.

Проте високодостовірна різниця виявилася за довічним надоєм, яка свідчить про непрямий вплив, у якості предиктора, віку телиць при першому осіменінні на дану ознаку. Вона склала у порівнянні з групою осіменіння у віці 14-15 місяців 10451 кг $(\mathrm{P}<0,001), 3040$ кг $(\mathrm{P}<0,01)$ у порівнянні 3 групою осіменіння у віці 20-21 міс. та 11519 кг $(\mathrm{P}<0,001)$ у порівнянні з групою осіменіння у віці 22 міс. і старше.

Вплив віку телиць за першого плідного осіменіння на продуктивне довголіття корів голштинської породи

\begin{tabular}{|c|c|c|c|c|c|c|}
\hline \multirow{3}{*}{ Голів } & \multirow{3}{*}{$\begin{array}{l}\text { Вік при першому } \\
\text { заплідненні, міс. }\end{array}$} & \multicolumn{2}{|c|}{ Жива маса, кг } & \multicolumn{2}{|c|}{ Надій, кг } & \multirow{2}{*}{$\begin{array}{c}\text { Кількість лактацій, } \\
\text { шт. }\end{array}$} \\
\hline & & перше запліднення & перше отелення & перша лактація & довічний & \\
\hline & & \multicolumn{5}{|c|}{$\mathrm{x} \pm$ S.E. / Cv, \% } \\
\hline \multirow{2}{*}{88} & \multirow{2}{*}{$14-15$} & $355 \pm 9,9$ & $537 \pm 10,2$ & $6855 \pm 355,3$ & $33823 \pm 831,6$ & $4,1 \pm 0,31$ \\
\hline & & 11.4 & 12.3 & 22.7 & 19,7 & 15,4 \\
\hline \multirow{2}{*}{135} & \multirow{2}{*}{$16-17$} & $378 \pm 7,4$ & $565 \pm 8,9$ & $7412 \pm 285,2$ & $44274 \pm 715,3$ & $5,3 \pm 0,26$ \\
\hline & & 8,7 & 9,5 & 19,2 & 12,7 & 13,5 \\
\hline \multirow{2}{*}{148} & \multirow{2}{*}{$18-19$} & $382 \pm 4,2$ & $573 \pm 8,2$ & $7215 \pm 272,7$ & $43377 \pm 622,6$ & $5,2 \pm 0,27$ \\
\hline & & 6,8 & 7,8 & 20,3 & 18,6 & 12,5 \\
\hline \multirow{2}{*}{45} & \multirow{2}{*}{$20-21$} & $391 \pm 6,1$ & $582 \pm 11,4$ & $7025 \pm 411,7$ & $41234 \pm 852,5$ & $4,5 \pm 0,32$ \\
\hline & & 10,4 & 12,5 & 28,5 & 18,7 & 22,5 \\
\hline \multirow{2}{*}{19} & \multirow{2}{*}{22 і старше } & $412 \pm 9,4$ & $597 \pm 15,6$ & $6765 \pm 462,3$ & $32755 \pm 875,2$ & $4,1 \pm 0,32$ \\
\hline & & 12,6 & 17,6 & 25,8 & 19,6 & 17,3 \\
\hline
\end{tabular}

Селекціонерам добре відомо, що одним з найефективніших методів поліпшення тварин при чистопородному розведенні та одним із найдавніших методів, $є$ розведення за лініями. Кожна порода обов'язково структурована за лініями. Мета лінійного розведення - це розвиток і закріплення у потомства цінних ознак для отримання тварин зі стійкою спадковістю, племінне використання яких забезпечить істотний генетичний розвиток стада або породи в цілому. Разом з тим, лінійне розведення дозволяє розділити будь-яку породу або її регіональний масив на окремі неспоріднені групи тварин і спланувати підбір у товарному стаді таким чином, щоб не допустити випадкового інбридингу, тобто спадкового парування. Розрізняють генеалогічні і заводські лінії. До генеалогічної лінії відносять усіх нащадків родоначальника незалежно від якості тварин. Заводську лінію визнають лише в тому разі, якщо більшість тварин у ній мають визначні ознаки.

А наразі, поки що, головним доказом щодо впливу лінійної належності на показники господарськи корисних ознак служать експериментальні дослідження, у тому числі й з вивчення впливу лінії на ознаки відтворювальної здатності корів молочної худоби.

Тим більше, що у літературних джерелах повідомляється про такий вплив. Наприклад, авторами [11] встановлено, що корови-первістки різних ліній української чорнорябої молочної породи відрізняються між собою не лише за молочною продуктивністю, а й за відтворною здатністю. Кращим за показниками молочної продуктивності та відтворної здатності виявилося дочірнє потомство, яке належало до відомої лінії як у голштинській породі, так і в українській чорно-рябій, Елевейшна 1491007. При цьому у межах досліджуваних чотирьох ліній була встановлена наступна мінливість показників відтворної здатності - вік першого отелення корів коливався в межах 28,4 - 31,8 місяців; тривалість біологічних періодів (днів) була такою: сервіс-період 133-166; сухостійний період - 55-64; міжотельний період - 414 - 447. Коефіцієнт відтворної здатності у досліджуваних груп тварин коливався в межах 0,81 - 0,88; індекс осіменіння - 1,92 2,56 .

За результатами наших досліджень корів, які нале- 
жали до п'яти генеалогічних формувань, виявлена певна та, в окремих випадках порівнянь, достовірна мінливість показників відтворювальної здатності дочірнього потомства бугаїв-плідників оцінених ліній у межах піддослідних порід. Досліджувались найбільш поширені у стаді, з достатньою для математичної обробки кількістю тварин, наступні лінії: Маршала 2290977, П.Ф.А. Чіфа 1427381, Елевейшна 1491007, Валіанта 1650414 та Старбака 352790.

За усіма ознаками, які були досліджені у межах характеристики відтворювальної здатності корів різних ліній голшинської породи, кращі показники отримано від дочірнього потомства бугаїв заводської лінії Валіанта 1650414, табл. 5. За віком першого осіменіння та отелення різниця вияви- лась достовірною $(P<0,01)$ лише у порівнянні з ровесницями лінії Маршала 2290977 і становила відповідно 38 та 39 днів. Тривалість тільності обмежена біологічною особливістю корів і варіювала у межах 275-280 днів.

Що стосується такого важливого показника як тривалість першої лактації, то різниця між потомством оцінюваних ліній виявилася достовірною та більш суттєвою і становила від 61 до 83 днів $(P<0,001)$.

За показниками кількості осіменінь на одну телицю та корову після першого отелення також дещо кращими виявилися потомки бугаїв лінії Валіанта з різницею відповідно 0,1-0,3 та 0,1-0,4 спермодози на одне осіменіння і достовірною між крайніми варіантами $(\mathrm{P}<0,01)$.

Таблиця 5

\section{Відтворювальні якості тварин голштинської породи}

залежно від лінійної належності, $x \pm$ S.E.

\begin{tabular}{|l|c|c|c|c|c|}
\hline \multicolumn{1}{|c|}{ Показники } & \multicolumn{3}{c|}{ Лінія } \\
\cline { 2 - 6 } & $\begin{array}{c}\text { Маршала } \\
2290977 \\
(\mathrm{n}=29)\end{array}$ & $\begin{array}{c}\text { П.Ф.А. Чіфра } \\
1427381 \\
(\mathrm{n}=446)\end{array}$ & $\begin{array}{c}\text { Елевейшна } \\
1491007 \\
(\mathrm{n}=241)\end{array}$ & $\begin{array}{c}\text { Валіанта } \\
1650414 \\
(\mathrm{n}=44)\end{array}$ & $\begin{array}{c}\text { Старбака } \\
352790 \\
(\mathrm{n}=175)\end{array}$ \\
\hline Вік першого осіменіння, днів & $512 \pm 11,4$ & $482 \pm 7,3$ & $477 \pm 9,4$ & $474 \pm 9,2$ & $480 \pm 7,4$ \\
\hline Вік першого отелення, днів & $790 \pm 10,4$ & $759 \pm 6,9$ & $752 \pm 8,7$ & $751 \pm 8,2$ & $757 \pm 5,6$ \\
\hline Тривалість тільності, днів & $280 \pm 1,3$ & $277 \pm 0,5$ & $275 \pm 0,9$ & $277 \pm 1,1$ & $277 \pm 0,7$ \\
\hline Тривалість першої лактації, днів & $403 \pm 12,3$ & $386 \pm 6,7$ & $382 \pm 8,7$ & $320 \pm 12,4$ & $381 \pm 8,5$ \\
\hline Кількість осіменінь на одну телицю, шт. & $1,8 \pm 0,04$ & $1,6 \pm 0,05$ & $1,8 \pm 0,04$ & $1,5 \pm 0,03$ & $1,7 \pm 0,05$ \\
\hline Кількість осіменінь на одну корову після першого отелення, шт. & $2,3 \pm 0,10$ & $2,1 \pm 0,09$ & $2,4 \pm 0,12$ & $2,0 \pm 0,09$ & $2,4 \pm 0,11$ \\
\hline Жива маса ремонтних телиць при першому осіменінні, кг & $377 \pm 11,7$ & $381 \pm 3,1$ & $385 \pm 5,1$ & $395 \pm 7,1$ & $384 \pm 2,7$ \\
\hline Жива маса корів при першому отеленні, кг & $502 \pm 7,8$ & $488 \pm 2,9$ & $504 \pm 3,2$ & $527 \pm 8,6$ & $513 \pm 5,2$ \\
\hline
\end{tabular}

Жива маса корів свідчить про добрий розвиток ремонтних телиць при вирощуванні та $€$ запорукою максимальної реалізації продуктивності корів у дорослому стані. За цим показником також спостерігалася мінливість залежно від їхнього походження. Мабуть логічно, що кращими за живою масою при першому осіменінні були телиці, отримані від бугаїв лінії Валіанта 1650414.

Різниця між потомством за живою масою при першому осіменінні оцінюваних ліній становила від 10 до 18 кг, проте вона незначна і не є достовірною.

Мінливість за живою масою при першому отеленні оцінюваних ліній була дещо більш мінливою і становила 39 кг у порівнянні з ровесницями лінії П.Ф.А. Чіфра 1427381 та 25 у порівнянні $з$ групою лінії Маршала 2290977, а з іншими групами різниця у межах 14-23 кг виявилась недостовірною.

У табл. 6 представлені дані оцінки відтворювальної здатності корів української чорно-рябої молочної породи. Досліджувались ті самі лінії з яких кращими за оцінюваними ознаками виявилися також потомки бугаїв лінії Валіанта 1650414. Проте мінливість оцінюваних ознак виявилась дещо вищою і становила за віком першого осіменінні та першого отелення відповідно 15-108 та 10-105 днів, різниця між крайніми варіантами становили 93 та 95 днів з високою достовірністю при $\mathrm{P}<0,001$.

За тривалістю першої лактації корови лінії Валіанта 1650414 перевищували ровесниць від 39 днів $(\mathrm{P}<0,01)$ у порівнянні 3 дочками лінії П.Ф.А. Чіфра 1427381 до 77 днів ( $\mathrm{P}<0,001)$ у порівнянні з потомством лінії Старбака 352790.
Дещо кращим виявилося потомство бугаїв-плідників лінії Валіанта і за показниками кількості осіменінь на одну телицю та корову після першого отелення з різницею відповідно 0,2-0,3 та 0,2-0,5 спермодози на одне осіменіння і достовірною між крайніми варіантами $(P<0,01)$.

Різниця між голштинським дочірнім потомством за живою масою при першому осіменінні оцінюваних ліній становила від 4 до 29 кг, проте вона незначна, але є достовірною при порівнянні з групами ліній П.Ф.А. Чіфр 1427381 та Маршала 2290977 при $\mathrm{P}<0,01$ та $\mathrm{P}<0,05$ відповідно.

Мінливість за живою масою при першому отеленні оцінюваних ліній була достовірною і становила від 59 кг у порівнянні з ровесницями лінії Маршала 2290977 до 35 у порівнянні з групою лінії Старбака 352790.

У селекції сільськогосподарських тварин взагалі та молочної худоби зокрема досить важливо знати і оцінювати фактичну ситуацію щодо визначення які із низки генетичних чи паратипових факторів найбільш впливають на стан та розвиток тих чи інших селекціонованих ознак.

Встановити які із названих чинників і наскільки впливають на розвиток селекціонованих ознак дозволяють параметри популяційно-генетичних параметрів, до яких відносяться кореляційна мінливість та сила впливу організованого фрактору.

Розраховані коефіцієнти кореляції та сили впливу віку корів при першому отеленні на ознаки їхньої продуктивності у межах піддослідних порід наведені у табл. 7. 
Відтворювальні якості тварин української чорно-рябої молочної породи залежно від лінійної належності, $\mathrm{x} \pm$ S.E.

\begin{tabular}{|l|c|c|c|c|c|}
\hline \multicolumn{1}{|c|}{ Показники } & \multicolumn{4}{c|}{ Лінія } \\
\cline { 2 - 6 } & $\begin{array}{c}\text { Маршала } \\
2290977 \\
(\mathrm{n}=24)\end{array}$ & $\begin{array}{c}\text { П.Ф.А. Чіфа } \\
1427381 \\
(\mathrm{n}=443)\end{array}$ & $\begin{array}{c}\text { Елевейшна } \\
1491007 \\
(\mathrm{n}=69)\end{array}$ & $\begin{array}{c}\text { Валіанта } \\
1650414 \\
(\mathrm{n}=28)\end{array}$ & $\begin{array}{c}\text { Старбака } \\
352790 \\
(\mathrm{n}=94)\end{array}$ \\
\hline Вік першого осіменіння, днів & $589 \pm 11,3$ & $496 \pm 5,3$ & $511 \pm 8,2$ & $481 \pm 9,2$ & $573 \pm 5,6$ \\
\hline Вік першого отелення, днів & $869 \pm 10,8$ & $774 \pm 5,7$ & $789 \pm 9,4$ & $764 \pm 8,5$ & $854 \pm 4,9$ \\
\hline Тривалість тільності, днів & $278 \pm 1,1$ & $278 \pm 0,5$ & $278 \pm 0,9$ & $279 \pm 1,1$ & $280 \pm 0,5$ \\
\hline Тривалість першої лактації, днів & $430 \pm 14,2$ & $393 \pm 6,4$ & $405 \pm 15,9$ & $354 \pm 11,6$ & $431 \pm 12,4$ \\
\hline Кількість осіменінь на одну телицю, шт. & $1,9 \pm 0,11$ & $1,6 \pm 0,09$ & $1,8 \pm 0,10$ & $1,6 \pm 0,05$ & $1,8 \pm 0,09$ \\
\hline Кількість осіменінь на одну корову після першого отелення, шт. & $2,4 \pm 0,10$ & $2,2 \pm 0,09$ & $2,5 \pm 0,12$ & $2,0 \pm 0,09$ & $2,3 \pm 0,11$ \\
\hline Жива маса ремонтних телиць при першому осіменінні, кг & $359 \pm 10,2$ & $355 \pm 8,3$ & $376 \pm 4,3$ & $384 \pm 5,2$ & $388 \pm 3,1$ \\
\hline Жива маса корів при першому отеленні, кг & $465 \pm 9,7$ & $472 \pm 9,7$ & $478 \pm 6,4$ & $524 \pm 7,3$ & $489 \pm 3,7$ \\
\hline
\end{tabular}

Таблиця 7

Коефіцієнти кореляції і сила впливу віку корів різного походження при першому отеленні на їхню молочну продуктивність

\begin{tabular}{|c|c|c|c|c|c|c|}
\hline \multirow{2}{*}{ Лактація } & \multicolumn{3}{|c|}{ Кореляційна мінливість між віком при першому отеленні із: } & \multicolumn{3}{|c|}{ Сила впливу (\%) віку при першому отеленніна: } \\
\hline & надоєм & вмістом жиру у молоці & кількістю молочного жиру & надій & вміст жиру у молоці & кількість молочного жиру \\
\hline \multicolumn{7}{|c|}{ Українська чорно-ряба молочна порода } \\
\hline 1 & $0,214^{*}$ & $-0,084$ & $0,254^{* *}$ & 24,6 & 18,3 & 25,3 \\
\hline 2 & 0,136 & $-0,065$ & $0,148^{*}$ & 21,7 & 16,5 & 22,4 \\
\hline 3 & 0,087 & $-0,032$ & 0,095 & 28,9 & 19,4 & 25,7 \\
\hline Краща & $0,274^{\star *}$ & $-0,085$ & $0,303^{* * *}$ & 31,4 & 21,7 & 28,5 \\
\hline \multicolumn{7}{|c|}{ Голштинська порода } \\
\hline 1 & $0,232^{* *}$ & $-0,077$ & $0,285^{\star \star *}$ & 26,4 & 19,7 & 27,6 \\
\hline 2 & $0,183^{*}$ & $-0,096$ & $0,202^{\star *}$ & 23,5 & 17,6 & 25,2 \\
\hline 3 & $0,124^{*}$ & $-0,046$ & $0,131^{*}$ & 26,7 & 21,8 & 27,8 \\
\hline Краща & $0,322^{* * *}$ & $-0,089$ & $0,344^{* * *}$ & 33,2 & 24,3 & 32,1 \\
\hline
\end{tabular}

Коефріцієнти кореляції між віком при першому отеленні та надоєм додатні від низьких до помірних і залежать від лактації. Найвищий коефіцієнт отриманий у віці кращої лактації (r=0,274; УЧРМ) та (r=0,322; ГП) свідчить, що добір за віком при першому отеленні може бути певною мірою ефективним. За вмістом жиру в молоці від'ємна кореляція вказує на відсутність ефективної селекції за цією ознакою. Тоді як добір за виходом молочного жиру буде також ефективним.

Про ефективність селекції за добором корів з урахуванням віку при першому отеленні свідчать показники сили впливу за усіма ознаками молочної продуктивності, які найвищі за величиною надою, особливо за кращу лактацію (31,4\% УЧРМ) та (33,2\%; ГП), та загальним виходом молочного жиру (28,5\%; УЧРМ) та (32,1\%; ГП).

Таким чином, за результатами власних досліджень встановлено залежність молочної продуктивності корів від віку їх першого осіменіння і першого отелення у піддослідних порід підприємства «Глобинський м'ясо-молочний комплекс». Найвищими надоями характеризувалися корови, яких вперше осіменяли у віці 16-19 місяців і вік першого отелення у яких становив 25-28 місяців. Частка впливу віку першого отелення на показники молочної продуктивності корів (надій, вміст жиру в молоці, кількість молочного жиру) знаходилася в межах 16,5-31,4\% (ЧРМП) та 17,6-33,2\% (ГП).

Висновки. Встановлено міжпородну мінливість за молочною продуктивністю та відтворними якостями залежно від впливу генетичних та паратипових чинників у порівняльному аналізі показників голштинської та української чорнорябої молочної порід. Отримані результати виявилися на користь тварин голштинської породи.

\section{Список використаної літератури:}

1. Безгин В. И., Поварова О. В. Влияние возраста и живой массы телок при первом оплодотворении на молочную продуктивность. Зоотехния. 2013. №1. С. 24-25.

2. Братушка Р. В. Влияние возраста первого отела на эффективность хозяйственного использования коров украинской черно-пестрой молочной породы. Розведення і генетика тварин. 2013. Вип. 47. С. 119-125.

3. Варпіховський Р. Л. Вплив генотипових і фенотипових чинників на молочну продуктивність корів. Wschodnioeuropejskie Czasopismo Naukowe (East European Scientific Journal. 2019. №11 (51). C. 34-43.

4. Ведмеденко О. В. Вплив генотипових та паратипових факторів на молочну продуктивність корів. Подільський вісник: сільське господарство, техніка, економіка. Сільськогосподарські науки. 2019. Вип. 30. С. 31-38.

5. Войтенко С. Л., Карунна Т. І., Шаферівський Б. С., Желізняк І. М. Вплив генотипових та паратипових факторів на реалізацію молочної продуктивності корів. Вісник Сумського національного аграрного університету. Серія «Тваринництво», 2019. Вип. 1-2 (36-37). С. 21-26.

6. Гайдукова Е. В., Тютюникова А. В. Связь молочной продуктивности холмогорских коров с продолжительностью сервис-периода. Зоотехния. 2013. № 2. С. 14-15. 
7. Жукова С, С., Гудыменко В. И. Использование голштинов в совершенствованиии черно-пестрой породы. Вестник Курской гос. С.-х. академии. 2011. № 4. С. 52-55

8. Зернина С. Г. Влияние возраста первого отела на сроки использованяи коров в ЗАО «Любань» Ленинградской области. Научное обеспечение развития АПК в условиях импортозамещения: сборник научных трудов. СанктПетербург, 2016. 4. 1. C. $200-202$.

9. Інструкція зі штучного осіменіння корів і телиць / М-во аграр. політики України, Нац. об-ня по плем. справі у тваринництві “Укрплемоб”єднання”; Ю. Ф. Мельник, М. В. Зубець, В. П. Буркат, І. С. Воленко, В. П. Алейніков, А. В. Маєвський, А. П. Кругляк, Г. С. Шарапа, Ф.І.Осташко, Г. Г. Харута, Г.І. Приткова, В. М. Горжеєв, О. Г. Шафрарук, В. О. Пасічник. К., 2001. 40 с.

10. Кальчук Л. А. Зв'язок молочної продуктивності з показниками відтворної здатності та господарського використання у корів чорно-рябої молочної породи. Науково-технічний бюлетень Інституту тваринництва. Харків, 2001. Вип. 80. С. 64-67.

11. Кальчук Л. А., Попадюк Т. С. Продуктивні та відтворні якості корів-первісток різного походження. Вісник Сумського національного аграрного університету. Серія «Тваринництво», 2014. Вип. 2/2 (25). С. 52-55.

12. Караба В. И., Петрович Э. А. Продуктивность первотелок в зависимости от возраста и живой массы ремонтного поголовья. Збірник наукових праць Таврійського державного агротехнологічного університету (економічні науки). 2014. №3(27). С. 75-78.

13. Кузебний С. В., Шарапа Г. С., Демчук С. Ю., Бойко О. В., Плотко Т.С., Шикова Н. В. Методи підвищення репродуктивної здатності молочних корів : рекомендації. Чубинське, 2018. 24 с.

14. Литвиненко Т. В., Бунь Ю. С. Відтворна здатність високопродуктивних корів голштинської породи в умовах лісостепу України. Вісник Сумського НАУ. Серія «Тваринництво». 2013. Вип. 1.(22). С. 122-125.

15. Мазур Н. П., Федорович Є. І., Федорович В. В. Продуктивне довголіття молочної худоби за різних методів розведення. Розведення і генетика тварин. 2018. Вип. 55. С. 102-112.

16. Мачульний В.В. Продуктивність корів українських чорно-рябої та червоно-рябої молочних порід. Розведення і генетика тварин. 2016. № 51. С. 112-118.

17. Меркурьева Е. К. Генетические основы селекции в скотоводстве. М.: Колос, 1977. 240 с.

18. Обливанцов В. В. Вплив віку першого отелення на продуктивні та відтворні якості корів сумського внутріпородного типу української чорно-рябої молочної породи. Вісник Сумського національного аграрного університету. 2015. Вип.6(28). С.46-51.

19. Пелехатий М. С., Піддубна Л. М., Кочук-Ященко О. А., Кучер Д. М. Порівняльна характеристика продуктивності корів-первісток сучасних молочних порід в умовах одного господарства. Біологія тварин. 2017. Т. 19. № 3. С. 69-76.

20. Піщан С. Г., Литвищенко Л. О., Гончар А. О. Реалізація генетичного потенціалу молочної продуктивності голштинської худоби за інтенсивної технології експлуатації. Зернові культури. 2017. Том 1, № 1, С. 147-153.

21. Салогуб А. М., Хмельничий Л. М. Особливості лінійиого розведення в селекційному поліпшенні продуктивності корів племінного стада. Збірник наукових праць Вінницького НАУ. Серія: Сільськогосподарські науки. - Вінниця. 2010. Вип. 5. С. 129-133.

22. Салогуб А. М., Хмельничий Л. М. Результати оцінки корів української бурої молочної породи в аспекті формування генотипової структури стада. Науково-технічний бюлетень Інституту тваринництва НААН України. 2010. № 102. С. 127-133.

23. Титаренко І. В., Даниленко В. П., Буштрук М. В., Старостенко І. С. Оцінка та відбір молочної худоби за відтворною здатністю. Технологія виробництва і переробки продукції тваринництва. 2014. №2. С. 21-25.

24. Федорович Є. І., Бабік Н. П. Вплив віку першого отелення корів молочних порід на їх продуктивне довголіття. Науково- інформаційний вісник біолого- технологічного факультету. Херсон: ХДАУ, ВЦ «Колос». 2017. Вип. 9. С. 120-127.

25. Федорович Є. І., Сірацький Й. 3. Вплив тривалості сухостійного, сервіс- і міжотельного періодів на молочну продуктивність корів західного внутрішньопородного типу чорно-рябої породи. Тваринництво України. 2005. № 1. С. 16-18.

26. Хмельничий Л. М., Вечорка В. В. Генетичні чинники впливу на продуктивність корів української чорно-рябої молочної породи. Розведення і генетика тварин. - К. - 2019. - Вип. 57 - С. 22-28. DOI: https://doi.org/10.31073/abg.57.03

27. Хмельничий Л. М., Вечорка В. В. Особливості молочної продуктивності генеалогічних фоормувань української чорно-рябої молочної породи. Матеріали міжн. науково-практ. конфреренції "Актуальні проблеми підвищення якості та безпека виробництва й переробки продукції тваринництва”. 14 лютого 2020 року. Дніпро. 2020. С. 151-153.

28. Хмельничий Л. М., Вечорка В. В. Формування ознак молочної продуктивності корів української чорно-рябої молочної породи під впливом генетичних чинників. Вісник Сумського національного аграрного університету. Серія «Тваринництво». 2019. Вип. 3(38). C.62-72. DOI: https://doi.org/10.32845/bsnau.lvst.2019.3.9

29. Хмельничий Л. М., Супрун І. О., Бардаш Д. О. Довічна продуктивність корів української червоно-рябої молочної породи за різних варіантів підбору. Вісник Сумського НАУ. Серія «Тваринництво». 2021. Вип. 1(44). С.29-35. DOI: https://doi.org/10.32845/bsnau.Ivst.2021.1.4

30. Ali William Canaza-Cayoa, Paulo Savio Lopesb, Jaime Araujo Cobuci, Marta Fonseca Martinsd and Marcos Vinicius Gualberto Barbosa da Silvad. Genetic parameters of milk production and reproduction traits of Girolando cattle in Brazil. Italian journal of animal science. 2018. Vol. 17. №. 1. pp. 22-30. https://doi.org/10.1080/1828051X.2017.1335180

31. Vanek D. A relationship between production and reproduction traits in cows of Czech Pied cattle. Czech J. Anim. Sci. 2004. 49(4). pp. 131-136.

\section{References:}

1. Bezgin, V.I. and Povarova, O.V., 2013. Vliyanie vozrasta i zhivoy massy telok pri pervom oplodotvorenii na molochnuyu produktivnost' [Influence of age and live weight of heifers at first insemination on milk production]. Zootekhniya, no. 1, pp. 24-25.

2. Bratushka, R.V., 2013. Vliyanie vozrasta pervogo otela na effektivnost' khozyaystvennogo ispol'zovaniya korov ukrainskoy cherno-pestroy molochnoy porody [Influence of the first calving age on the efficiency of cows economic use of Ukrainian Black-and- 
White dairy breed]. Rozvedennia i henetyka tvaryn, issue 47, pp. 119-125.

3. Varpikhovskyi, R.L., 2019. Vplyv henotypovykh i fenotypovykh chynnykiv na molochnu produktyvnist koriv [Influence of genotypic and phenotypic factors on cows milk productivity]. Wschodnioeuropejskie Czasopismo Naukowe (East European Scientific Journal, no. 11(51), pp. 34-43.

4. Vedmedenko, O.V., 2019. Vplyv henotypovykh ta paratypovykh faktoriv na molochnu produktyvnist koriv [Influence of genotypic and paratypic factors on cows milk productivity]. Podilskyi visnyk: silske hospodarstvo, tekhnika, ekonomika. Silskohospodarski nauky, issue 30, pp. 31-38.

5. Voitenko, S.L., Karunna, T.I., Shaferivskyi, B.S. and Zhelizniak, I. M., 2019. Vplyv henotypovykh ta paratypovykh faktoriv na realizatsiiu molochnoi produktyvnosti koriv [Influence of genotypic and paratypic factors on the realization of cows milk productivity]. Visnyk Sumskoho natsionalnoho ahrarnoho universytetu. Seriia «Tvarynnytstvo», issue 1-2, pp. 21-26.

6. Gaydukova, E.V. and Tyutyunikova, A.V., 2013. Svyaz' molochnoy produktivnosti kholmogorskikh korov s prodolzhitel'nost'yu servis-perioda [Relationship between the milk productivity of Kholmogory cows and the service period duration]. Zootekhniya, no. 2, pp. 14-15.

7. Zhukova, S.S. and Gudymenko, V.I., 2011. Ispol'zovanie golshtinov v sovershenstvovaniii cherno-pestroy porody [The use of Holsteins in the improvement of Black-and-White breed]. Vestnik Kurskoy gos. s.-kh. akademii, no. 4, pp. 52-55.

8. Zernina, S.G., 2016. Vliyanie vozrasta pervogo otela na sroki ispol'zovanyai korov v ZAO «Lyuban'» Leningradskoy oblasti [Influence of the first calving age on the terms of cows use in CJSC "Lyuban", Leningrad region]. Nauchnoe obespechenie razvitiya APK v usloviyakh importozameshcheniya: sbornik nauchnykh trudov. Sankt-Peterburg, Ch. 1, pp. 200-202.

9. Melnyk, Yu. F., Zubets, M. V., Burkat, V. P., Volenko, I. S., Aleinikov, V. P., Maievskyi, A. V., Kruhliak, A. P., Sharapa, H. S., Ostashko, F. I., Kharuta, H. H., Prytkova, H. I., Horzheiev, V. M., Shafaruk, O. H. and Pasichnyk, V. O., 2001. Instruktsiia zi shtuchnoho osimeninnia koriv $i$ telyts / Ministerstvo ahrarnoi polityky Ukrainy, Natsionalne obiednannia po plemenni spravi u tvarynnytstvi "Ukrplemobiednannia" [Instruction on artificial insemination of cows and heifers / Ministry of Agrarian Policy of Ukraine, National Association for Breeding in Animal Husbandry "Ukrplemobednannia"]. Kyiv.

10. Kalchuk, L.A., 2001. Zviazok molochnoi produktyvnosti z pokaznykamy vidtvornoi zdatnosti ta hospodarskoho vykorystannia u koriv chorno-riaboi porody [The relationship of milk productivity with indicators of reproductive ability and economic use in Black-and-White cows]. Naukovo-tekhnichnyi biuleten. Kharkiv, issue 80, pp. 64-67.

11. Kalchuk, L.A. and Popadiuk, T.S., 2014. Produktyvni ta vidtvorni yakosti koriv-pervistok riznoho pokhodzhennia [Productive and reproductive qualities of first-born cows of different origins]. Visnyk Sumskoho natsionalnoho ahrarnoho universytetu. Seriia «Tvarynnytstvo», issue 2/2(25), pp. 52-55.

12. Karaba, V.I. and Petrovich, E.A., 2014. Produktivnost' pervotelok v zavisimosti ot vozrasta i zhivoy massy remontnogo pogolov'ya [Productivity of first-calf heifers depending on age and live weight of replacement livestock]. Zbirnyk naukovykh prats Tavriiskoho derzhavnoho ahrotekhnolohichnoho universytetu (ekonomichni nauky), no. 3(27), pp. 75-78.

13. Kuzebnyi, S.V., Sharapa, H.S., Demchuk, S.Yu., Boiko, O.V., Plotko, T.S. and Shykova, N.V., 2018. Metody pidvyshchennia reproduktyvnoi zdatnosti molochnykh koriv: rekomendatsii [Methods for increasing the reproductive ability of dairy cows: recommendations]. Chubynske.

14. Lytvynenko, T.V. and Bun, Yu.S., 2013. Vidtvorna zdatnist vysokoproduktyvnykh koriv holshtynskoi porody v umovakh lisostepu Ukrainy [Reproductive ability of highly productive cows of Holstein breed in the forest-steppe conditions of Ukraine]. Visnyk Sumskoho NAU. Seriia «Tvarynnytstvo», issue 1(22), pp. 122-125.

15. Mazur, N.P., Fedorovych, Ye.I. and Fedorovych, V.V., 2018. Produktyvne dovholittia molochnoi khudoby za riznykh metodiv rozvedennia [Productive longevity of dairy cattle by different breeding methods]. Rozvedennia i henetyka tvaryn, issue 55, pp. $102-112$.

16. Machulnyi, V.V., 2016. Produktyvnist koriv ukrainskykh chorno-riaboi ta chervono-riaboi molochnykh porid [Productivity of Ukrainian cows of Black- and Red-and-White dairy breeds]. Rozvedennia i henetyka tvaryn, no. 51, pp. 112-118.

17. Merkur'eva, E.K., 1977. Geneticheskie osnovy selektsii v skotovodstve [Genetic bases of selection in the animal husbandry]. Moskva: Kolos.

18. Oblyvantsov, V.V., 2015. Vplyv viku pershoho otelennia na produktyvni ta vidtvorni yakosti koriv sumskoho vnutriporodnoho typu ukrainskoi chorno-riaboi molochnoi porody [Influence of the first calving age on productive and reproductive qualities of cows Sumy intrabreed tipe of the Ukrainian Black-and-White dairy breed]. Visnyk Sumskoho NAU. Seriia "Tvarynnytstvo», issue 6(28), pp. 46-51.

19. Pelekhatyi, M.S., Piddubna, L.M., Kochuk-Yashchenko, O.A. and Kucher, D.M., 2017. Porivnialna kharakterystyka produktyvnosti koriv-pervistok suchasnykh molochnykh porid v umovakh odnoho hospodarstva [Comparative characteristics of the first-calf cows productivity of modern dairy breeds in the one farm conditions]. Biolohiia tvaryn, no. 3, pp. 69-76.

20. Pishchan, S.H., Lytvyshchenko, L.O. and Honchar, A.O., 2017. Realizatsiia henetychnoho potentsialu molochnoi produktyvnosti holshtynskoi khudoby za intensyvnoi tekhnolohii ekspluatatsii [Realization of the milk productivity genetic potential of Holstein cattle at intensive technology of operation]. Zernovi kultury, no. 1, pp. 147-153.

21. Salohub, A.M. and Khmelnychyi, L.M., 2010. Osoblyvosti liniinoho rozvedennia v selektsiinomu polipshenni produktyvnosti koriv pleminnoho stada [Features of linear breeding in selection improvement of cow's productivity in the breeding herd]. Zbirnyk naukovykh prats Vinnytskoho NAU. Seriia: Silskohospodarski nauky, issue 5, pp. 129-133.

22. Salohub, A.M. and Khmelnychyi, L.M., 2010. Rezultaty otsinky koriv ukrainskoi buroi molochnoi porody v aspekti formuvannia henotypovoi struktury stada [The results of cows evaluation of the Ukrainian Brown dairy breed in the aspect of formation of the herd genotypic structure]. Naukovo-tekhnichnyi biuleten Instytutu tvarynnytstva NAAN Ukrainy, no. 102, pp. 127-133.

23. Tytarenko, I.V., Danylenko, V.P., Bushtruk, M.V. and Starostenko, I.S., 2014. Otsinka ta vidbir molochnoi khudoby za 
vidtvornoiu zdatnistiu [Evaluation and selection of dairy cattle by reproductive ability]. Tekhnolohiia vyrobnytstva i pererobky produktsii tvarynnytstva, no. 2, pp. 21-25.

24. Fedorovych, Ye.I. and Babik, N.P., 2017. Vplyv viku pershoho otelennia koriv molochnykh porid na yikh produktyvne dovholittia [Influence of the first calving age of dairy cows on their productive longevity]. Naukovo-informatsiinyi visnyk biolohotekhnolohichnoho fakultetu. Kherson: KhDAU, VTs «Kolos», issue 9, pp. 120-127.

25. Fedorovych, Ye.I. and Siratskyi, Y.Z., 2005. Vplyv tryvalosti sukhostiinoho, servis- i mizhotelnoho periodiv na molochnu produktyvnist koriv zakhidnoho vnutrishnoporodnoho typu chorno-riaboi porody [Influence of the duration of dry, service and interbody periods on the cow's milk productivity of the western intrabreed type of the Black-and-White breed]. Tvarynnytstvo Ukrainy, no. 1, pp. 16-18.

26. Khmelnychyi, L.M. and Vechorka, V.V., 2019. Genetic factors of influence on the productivity of cows of Ukrainian Blackand-White dairy breed [Henetychni chynnyky vplyvu na produktyvnist koriv ukrainskoi chorno-riaboi molochnoi porody]. Rozvedennia i henetyka tvaryn, issue 57, pp. 22-28. DOI: https://doi.org/10.31073/abg.57.03

27. Khmelnychyi, L.M. and Vechorka, V.V., 2020. Osoblyvosti molochnoi produktyvnosti henealohichnykh formuvan ukrainskoi chorno-riaboi molochnoi porody [Features of milk productivity of genealogical formations of the Ukrainian Black-and-White dairy breed]. "Actual problems of quality improvement and safety of production and processing of livestock products", Proceedings of the International Conference, Dnipro, February 14, 2020. Dnieper, pp. 151-153.

28. Khmelnychyi, L.M. and Vechorka, V.V., 2019. Formation of milk productivity traits of cows of Ukrainian Black-and-White dairy breed under the influence of genetic factors [Formuvannia oznak molochnoi produktyvnosti koriv ukrainskoi chorno-riaboi molochnoi porody pid vplyvom henetychnykh chynnykiv]. Visnyk Sumskoho natsionalnoho ahrarnoho universytetu. Seriia «Tvarynnytstvo», issue 3(38), pp. 62-72. DOI: https://doi.org/10.32845/bsnau.lvst.2019.3.9

29. Khmelnychyi, L.M., Suprun, I.O. and Bardash, D.O., 2021. Lifetime productivity of cows of Ukrainian Red-and-White dairy breed under various options of selection [Dovichna produktyvnist koriv ukrainskoi chervono-riaboi molochnoi porody za riznykh variantiv pidboru]. Visnyk Sumskoho NAU. Seriia "Tvarynnytstvo», issue 1(44), pp. 29-35. DOI: https://doi.org/10.32845/bsnau.lvst.2021.1.4

30. Ali William Canaza-Cayoa, Paulo Savio Lopesb, Jaime Araujo Cobuci, Marta Fonseca Martinsd and Marcos Vinicius Gualberto Barbosa da Silvad. 2018. Genetic parameters of milk production and reproduction traits of Girolando cattle in Brazil. Italian journal of animal science, no. 1, pp. 22-30. https://doi.org/10.1080/1828051X.2017.1335180

31. Vanek, D. A., 2004. Relationship between production and reproduction traits in cows of Czech Pied cattle. Czech J. Anim. Sci., no. 49(4). pp. 131-136.

Shpetnyi Mykola Borysovych, PhD of Agricultural Sciences, Docent

Zabolotna Vira Kostiantynivna, student of the Faculty of Biology and Technology

Hryshyn Serhii Yuriiovych, student of the Faculty of Biology and Technology

Sumy nanional agrarian university (Sumy, Ukraine)

Milk productivity and reproductive ability of cows, depending on the genetic and paratypic factors

Research has been carried out to study of milk productivity traits and reproductive ability of animals of the Holstein and Ukrainian Black-and-White dairy breeds in the conditions of the industrial enterprise "Globinskyi meat and dairy complex" of the Poltava region. The interbreed variability was determined in milk yield by which the leading cows of Holstein breed with a yield of 7334 $\mathrm{kg}$ according to the first lactation data with an excess of Ukrainian Black-and-White peers by $609 \mathrm{~kg}(P<0.001)$. According to the data of the second, third and best lactations, the milk yield advantage was 1542 and 2531, 1678 and 2581, 2179 and $3237 \mathrm{~kg}$, respectively, with a high and reliable difference in all comparisons. A comparative analysis of the reproductive ability indicators of cows testified that the Holsteins were more early maturing, since they first inseminated at the age of 461.6 days, which was on 42.4 days earlier than peers of Ukrainian Black-and-White dairy breed. The duration of cow's service period of Holstein breed was 109 days, which was less than that in peers of the Ukrainian Black-and-White dairy cows at the same age, the difference of 14 days was highly reliable $(P<0.001)$. The difference in live weight of repair heifers of the Holstein breed in $19 \mathrm{~kg}$ compared to peers of Ukrainian Black-and-White was reliable at the level of the last threshold $(P<0.001)$, as well as the body weight at the first calving by $35 \mathrm{~kg}$. $A$ reliable influence of the first fruitful insemination age of heifers and calving on the milk productivity indicators has been determined. High rates of the first lactation and lifelong milk yield in cows of Ukrainian Black-and-White dairy breed were at their insemination at 16-17 months and calving at 25-26 months with milk yield in the first lactation and life - 6952 and $37674 \mathrm{~kg}$, and in cows Holstein breed, these indicators were 7412 and $44274 \mathrm{~kg}$., respectively. The reliable variability of reproductive ability indicators of the daughter offspring of sires of the evaluated lines was revealed within the experimental breeds. The correlation coefficients were established between age at first calving and milk yield, which ranged from low $(r=0.087)$ to moderate $(r=0.214)$ and depended on lactation. The highest correlation obtained at the age of best lactation $(r=0.274)$ indicated that selection by age at first calving can be to a certain extent effective. In terms of fat content in milk, negative correlations $(r=-0.032 \ldots-0.085)$ indicated the lack of effective selection for this trait. Whereas selection for milk fat yield will also be effective $(r=0.095-0.303)$, especially for better lactation. The effectiveness of cows selection, taking into account age at the first calving, was evidenced by the power of influence indicators for all milk productivity traits, which were the highest in terms of milk yield, especially for better lactation (31.4\%) and the total yield of milk fat (28.5\%).

Key words: Holstein, Ukrainian Black-and-White dairy, milk yield, fat, protein, reproductive qualities, correlation, power of influence.

Дата надходження до редакції: 29.09.2021 р. 